\title{
ON THE PORCELLANID CRAB, PORCELLANELLA TRILOBA WHITE (CRUSTACEA-ANOMURA), A COMMENSAL ON SEA PEN; WITH REMARKS ON ALLIED SPECIES ${ }^{1}$
}

\author{
By C. SankarankutTy \\ Central Marine Fisheries Research Institute, Mandapam Camp
}

Recently, in a note on animal association, Jones (1959) recorded a porcellanid crab on the sea pen Pteroeides esperi Herklots, commonly occurring in the Gulf of Mannar. The porcellanid crab was passed on to me for identification, which I identify here as Porcellanella triloba White.

Porcellanella (Porcellanidae-Anormura) was recorded for the first time in 1852 during the voyage of H.M.S. 'Rattlesnake' by White, who designated it by the species $P$. triloba from Cape Capricon, Australia. Subsequently Stimpson (1858) described another species $\boldsymbol{P}$. picta from Hong Kong. In addition, $P$. triloba has also been recorded from Celebes Sea, Falkland Island and Rameswaram by Henderson and from Zanzibar by Barnard (1950). Miyake $(1942,1943)$ described Porcellanella picta and $P$. triloba from Bingo-Nanda and Palau Island respectively.

\section{PORCELLANELLA TRILOBA WHITE}

Porcellanella triloba, White, 1852, pp. 394-395, Fig. 2, 2 a.

Porcellanella picta, Stimpson, 1858, pp. 243-244.

Porcellanella triloba, Haswell, William, 1882, p. 149.

Porcellanella triloba, Henderson, 1888, pp. 112-113.

Porcellanella triloba, Henderson, 1893, p. 429.

Porcellanella triloba, Barnard, 1950, p. 891.

Porcellanella picta, Miyake, 1943, pp. 134-137, Figs. 54, 55 A-F.

Material: Six mature specimens of which four are females and the rest males.

Locality: Vedalai, in Gulf of Mannar; Often caught in shore seines along with the host, Pteroeides esperl Herklots.

Description: The carapace is longer than broad and slightly convex from side to side. The dorsal profile of the carapace rises behind the frontal lobes and runs more or less straight to the posterior end. The dorsal surface of carapace has

${ }^{2}$ Published with the kind permission of the Director, Central Marine Fisheries Research Institute, Mandapam Camp. 
transverse striae, clearer towards the anterior end and sides. Front is trilobed, the median lobe being longer and broader but subacute as the lateral lobes. The borders of all the lobes appear smooth, but minutely serrated under magnification. The median frontal lobe has a fringe of minute hairs pointing laterally, all of them arising in a line just below the border of the lobe. The ventral keel of the median lobe originates from the base and runs up to $2 / 3$ the length of the lobe. The inner border of the lateral lobe is almost straight whereas its outer border is rounded. The margin of the carapace overlying the eye peduncle and antenna is concave. The carapace is widest a little behind the insertion of the antenna, from whence it narrows posteriorly. The posterior border of the carapace is concave.

The basal antennular joint (Fig, 10) is lobular and has a flat ventral side and carries two teeth at the inner distal margin, the inner of the two being smaller. The spiny triangular lobe located just in front of the insertion of the antenna covers only a part of the ventral side of the eye peduncle. Below this spiny projection is a small and blunt projection of pterygostomial region, with a cleft between the two. The pterygostomial region also possesses striation. The antennal peduncle consists of three enlarged segments of which the second is largest and third the shortest. The first segment is free from the margin of the carapace and visible in the dorsal view of the animal. The antennal flagellum is composed of numerous segments.

The chelipeds are unequal, either the left or the right being larger. The inner distal corner of ischium as well as merus are produced into triangular lobes, the lobe on the merus is the larger. The carpus is longer than broad and has a longitudinal groove on its inner side. Manus is a flattened segment with a keeled outer border, and its length including the fixed finger approximates the length of carapace. Manus is broadest midway between its base on the outer side and the proximal end of dactylus. On the inner side of the manus is a thick fringe of plumose hair, originating at the broadest part of the manus and ending in between the fingers. The fingers have flat cutting edges, the outer side forming a raised feebly toothed cutting edge. The tips of the fingers are hooked and cross each other. The carpus and manus are clearly striated on the dorsal side, less distinct on the manus.

The first three ambulatory legs (Fig. 9) are of the same size, the merus is longer than broad (high) and flattened from side to side. The carpus and propodus when measured along the outer side appear to be of same length. The borders of all the segments are smooth. There are two spinules at the distal end on the ventral side of the propodus. The dactylus (Fig. 7, 8) is curved and carries four spinules, of which second is the largest. The fourth leg is characteristically reduced.

The ischium of the external maxilliped, at the distal end on the outer side has a triangular lobe. Propodus and carpus when measured along the outer border are equal in length. Merus, ischium and also the exopod have transverse striations on their outer side.

The abdomen (Fig. 6) consists of six segments and telson. Segments 2, 3, 4 and 5 are equal in breadth. Telson is broader than long and has a median triangular plate with a transverse division on either side. The distal end of telson and borders of uropod, excepting the proximal outer half of endopod, carry plumose bipinnate setae.

Colouration: The ground colouration of the animal in living condition is milky white, turning slightly brownish on preservation. The carapace as well as 


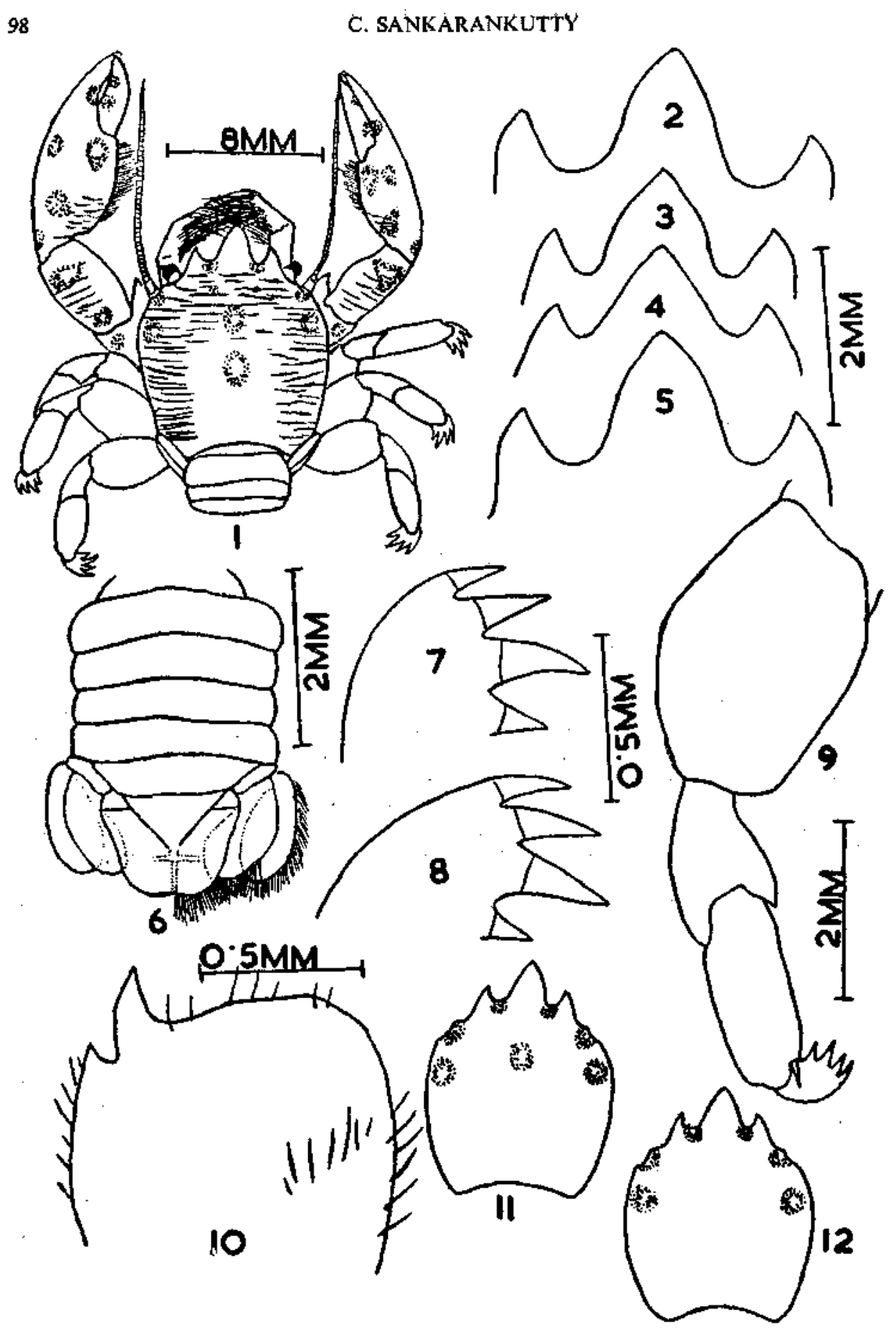

(1) Dorsal view of the animal. $(2,3,4$ and 5) Variations in the shape of frontal lobes. (6) Abdomen. (7 and 8) Dactylus of walking legs. (9) Walking leg. (10) Basal antennular segment. (11 and 12) Variation in the colouration of carapace. 
chelipeds have varying number of blotches, most of them being symmetrically arranged, with a few median blotches on the carapace. The carapace basically has the following blotches. A blotch is located between the median and lateral frontal lobes near the border. Another blotch is seen on the supra-antennal margin of the carapace and a similar one immediately behind. The carapace may have one or two median blotches. A few of the variations are shown in the figures (Figs. 1, 11 and 12). These blotches in fresh specimens are black in colour with a lighter centre, and quickly disappear on preservation. In a single specimen a blotch is seen at the base of the pterygostomial spine also. In still another specimen, merus, carpus and propodus of external maxilliped has a single blotch each.

Measurements (in millimeters) of a male and a female specimen :

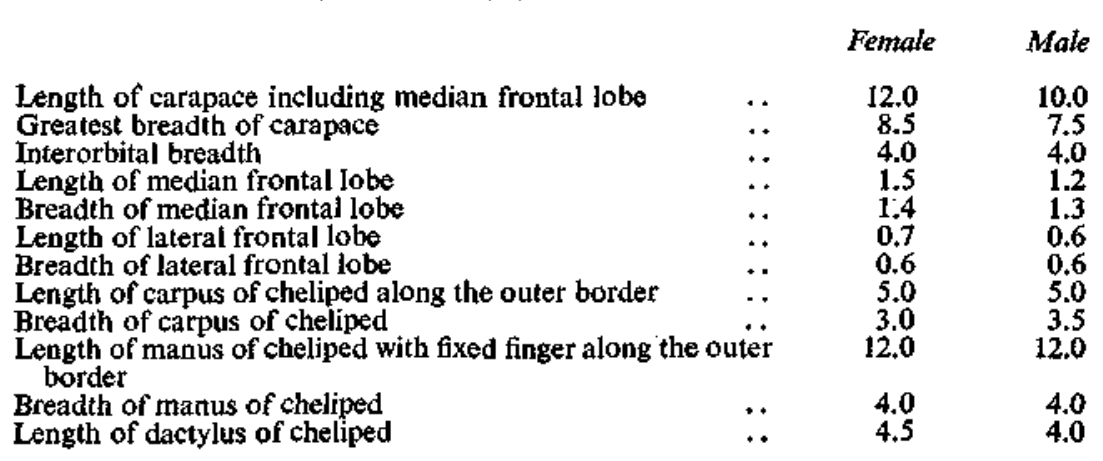

Distribution: Cape Capricon in Australia (White); Celebes Sea, Falkland Island, Rameswaram (Henderson); Zanzibar (Barnard); Hong Kong sea (Stimpson); Inland sea, Bingo Nada, Tosa, Tomioka, Amakusa (Miyake).

Remarks: Specimens in my collection are in perfect agreement with the original description and figure of $P$. triloba given by White and also with the colouration of the carapace described by Henderson. Stimpson also noticed similar colouration in his species $P$. picta. Henderson, on comparing the original specimens of both the species remarks, 'In White's species the median frontal projection but slightly exceeds the lateral ones, and its apex is rounded, while the first or most proximal of the four spinules on the ambulatory dactyli is very small ; in Stimpson's species the median frontal tooth is slightly longer and subacute, and the four spinules on the dactyli are subequal. The two species may yet be united, but at present may be kept separate :

A comparison of $P$. triloba and $P$. picta with specimens of the recent collection shows the following variations. In my material the median frontal lobe shows variation from subacute to rounded condition (Figs. 2, 3, $4 \&$ 5). Further, figures $7 \& 8$ clearly indicate the size variation of the most proximal spinule of the dactylus of the ambulatory legs. Hence the differentiation of $P$. triloba and $P$. picta based on the above characters does not seem to be tenable whereas these characters can be considered to be individual variations. As originally suggested by Henderson and also in the light of above observations, it is proposed to relegate $P$. picta Stimpson to the synonymy of $P$. triloba White.

Miyake (1942) described $P$. triloba from Palau Island off Malagal Islind, and has also figured the specimen. His figures, on comparing with the original figure 
given by White, shows some important differences. (1) The frontal lobes are very rounded. (2) The carapace is narrower. But the species $P$. picta described by him agrees in all respects with the specimens of my collection especially in the nature of basal antennular segment, nature of the front and size of the spinules on the dactylus. Hence I feel that $P$, picta described by him is actually $P$. triloba White while his $P$. triloba represents a species new to science.

\section{SUMMARY}

Porcellanella triloba White which is a common porcellanid crab commensal on the sea pen Pteroeides esperi Herklots has been redescribed in this paper. Porcellanella picta Stimpson is here considered as a synonym of $P$. triloba White and reasons have been given for doing so.

\section{ACKNOWLEDGEMENTS}

I wish to express my grateful thanks to Dr. S. Jones, Director, Central Marine Fisheries Research Institute for his guidance and encouragement. I am also thankful to Dr. Janet Haig of the Allan Hancock Foundation for going through the manuscript and offering valuable suggestions. I am indebted to Dr. R. P. Varma, Dr. E. G. Silas and Shri P. R. S. Tampi for constructive criticism.

\section{REFERENCES}

Barnard, K. H. 1950. Descriptive catalogue of South African Decapod Crustacea. Ann. S.Afr. Mus. $38: 819$.

Henderson, J, R. 1888. 'Anomura'Rep. Sci. Res. H.M.S. 'Challenger'. 27:112-113.

- 1893. 'A contribution to Indian carcinology'. Trans. Linn. Soc. London (Zool.) 5 (2) : 429 .

Haswell, W. A. 1882. Catalogue of the Australian stalk and sessile-eyed crustacea. Australian Museum, Sydney. 149.

JONES, S. 1959. Notes on animal associations. 1. A porcellanid crab on the sea pen, Pteroeides esperi Herkiots. J. Mar. biol. Ass. India, 1(2) : $178-179$.

MrYake, S. 1942. Studies on the decapod crustaceans of Micronesia. III. Porcellanidae. Palao trop. biol. Sta. Stud. $2: 368-370$.

- 1943. Studies on the crab-shaped Anomura of Nippon and adjacent waters. $J$. Dep. of Agric. Kyushu Univ. 7 (3): 134-137.

Stimpson, W. 1858. Prodromus discriptionis animalium evertebratorum quae in Expeditionae ad Oceanum Pacificum Septentrionalem, a Republica Federata missa, cadavaldaro Ringgold et Johanne Rodgers decibus, observavit et descripsit Pars VII Crustacea-Anomura. Proc. Acad. nat. Sci. Philadelphia $10: 243-244$.

Whrte, A. 1852. Macgillivrys voyage of H.M.S. ' Rattlesnake' I, (Appendix), 394-95. 